https://helda.helsinki.fi

\title{
Prophetic Intermediation in the Ancient Near East
}

\section{Nissinen, Martti Heikki}

Oxford University Press USA

2016

Nissinen , M H 2016 , Prophetic Intermediation in the Ancient Near East . in C J Sharp (ed.), pÿThe Oxford Handbook of the Prophets . Oxford University Press USA, New York, pp. 522.

http://hdl.handle.net/10138/319109

publishedVersion

Downloaded from Helda, University of Helsinki institutional repository.

This is an electronic reprint of the original article.

This reprint may differ from the original in pagination and typographic detail.

Please cite the original version. 


\title{
THE OXFORD HANDBOOK OF
}

\section{THE PROPHETS}

\author{
Edited by \\ CAROLYN J. SHARP
}

2016

OXFORD

UNIVERSITY PRESS 
CHAPTER 1

\title{
PROPHETIC \\ INTERMEDIATION IN \\ THE ANCIENT NEAR EAST
}

\author{
MARTTI NISSINEN
}

\begin{abstract}
"PROPHECY" and "prophet" are words that have many meanings. In modern languages, the word "prophecy" is sometimes used to refer to prediction of the future, and the word "prophet" to describe a person who claims, or is believed, to be able to tell what will happen in the future. In ancient sources and societies, however, the predictive activity of the people commonly called "prophets" is but another aspect of mediation of divine knowledge. Accordingly, the principal function of what is called "prophecy" in bibli$\mathrm{cal}$ and ancient Near Eastern scholarship is today seen as intermediation rather than prediction.
\end{abstract}

\section{PROPHECY AS INTERMEDiation}

As a scholarly concept, "prophecy" is created and maintained by the academic community that provides the matrix within which it works. In this sense, "prophecy" is a scholarly construct that must be defined and agreed upon (Nissinen 2013). There is a widespread consensus among biblical and ancient Near Eastern scholars to use the word "prophecy" for the intermediation of divine knowledge by non-technical means, constituting a process of communication consisting of four essential components: first, the allegedly divine sender of the message; second, the message proper, together with its verbal or symbolic performance; third, the prophet, that is, the transmitter of the message; and fourth, the recipient(s) of the message (Weippert 2014: 231-232; orig. 1988/1997). Moreover, the prophetic performance has to be acknowledged by a community that ultimately decides whether or not it was to be appreciated as transmitting a divine word. 
The prophetic process of communication is not a one-way street from the deity through the prophet and eventual go-betweens to the recipients, but a form of social communication: the community keeps prophecy alive and ultimately makes it functional.

The preceding definition of prophecy, albeit often with some modifications, is widely accepted (e.g., de Jong 2007: 31; Stökl 2012: 7-11); however, the consensus has not reached Classical scholars, who usually prefer to use the words "oracle" and "seers" for what biblical and ancient Near Eastern scholars call "prophecy" and "prophets" (cf. e.g., Flower 2008; Kajava [ed.] 2013). The divergent terminology is largely due to the centuries of separate lives of the academic disciplines, but to some extent also to differences in the source materials and the phenomena documented in them.

\section{Prophecy as Divination}

As another form of attaining divine knowledge, prophecy should not be regarded as distinct from divination, let alone as its antonym, but, rather, as one of its many modes. 'The basic motivation of divination grows out of uncertainty about the future and the risk human ignorance might cause when making important decisions, whether private or political. The very idea of divination presupposes the idea of superhuman agency managing things that happen in the world of humans; hence divination belongs to standard patterns of coping with superhuman agents (cf. Pyysiäinen 2009). Such patterns are historically and socially contingent and exist in different cultures independently from each other. In the ancient Eastern Mediterranean, divine knowledge was acquired by different means, especially by astrology, hepatoscopy, exorcism, and augury, typically practiced by highly educated people. Divinatory methods were based on the conviction that gods actually communicate with the people. Gods were thought to be free to communicate with anyone by any given means, but most divinatory methods required the management of specific techniques and skills, and not every person was acknowledged as a qualified diviner.

Since all divination is understood as communication between heaven and earth, every diviner, not just the prophet, is basically an intermediary between the human and divine worlds (Pongratz-Leisten 1999). What makes prophecy distinguishable from other forms of divination in the ancient world is the lack of the use of inductive or technical methodology, such as observing the livers of sacrificial animals, the stars, or the flight of birds. In contrast, prophecy is understood as a non-technical, intuitive, or inspired kind of divination, with the prophet acting as mouthpiece of the deity. Prophetic divination, unlike scholarly divination, was not related to scribal learning, systematic organization and categorization of phenomena, or any kind of empirical methodologies. No specific set of skills required of prophetic diviners can be discerned from the sources, but the ability to reach an altered state of consciousness and to combine it with a convincing public behavior and performance was probably a general expectation. 


\section{Who Are the "Prophets" in Ancient Texts?}

Persons acting as intuitive or inspired intermediaries are known by several designations in ancient Eastern Mediterranean texts, whether biblical and Near Eastern (Stökl 2012) or Greek (Lampinen 2013). The word family "prophet" in modern languages derives from the Greek prophètēs (masc.)/prophêtis (fem.), with which the Septuagint

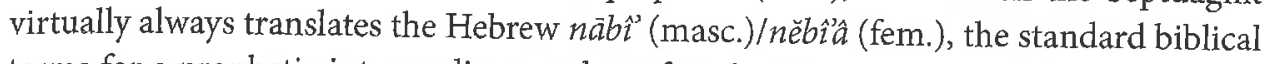
terms for a prophetic intermediary, male or female. Other common Hebrew designations for a prophetic intermediary are hözê and röè ("seer"), and nouns from the root $h z h$ are used for prophets in other Semitic languages as well.

In Greek sources, the use of the word prophètēs is less coherent. It may designate an inspired intermediary, but, as at Didyma, it could also be the title of the temple official who publicized the oracles of the female prophet called prophettis. Depending on the source, the prophetic intermediaries may carry other Greek titles, such as mantis (masc./fem.), which means "diviner" in general, and promantis, which is more often than not used for female prophets at Delphi and Didyma.

While the Greek terminology makes no strict distinction between inspired and technical divination, the cuneiform texts in the Akkadian language have specific vocabulary for prophetic intermediaries that never overlaps with designations of technical diviners. The most common word denoting a "prophet" is muhhûm (masc.)/muhhütum (fem.) in the Old Babylonian dialect, corresponding to the Neo-Assyrian mahhu $\hat{u}$ (masc.)) mahhütu (fem.). This word has a wide temporal and geographical distribution, and it is derived from the verb mahu ("to go into a frenzy"), which connects prophecy with an altered state of consciousness. Another designation known from Old Babylonian texts is äpilum (masc.) /äpiltum (fem.) ("answerer" or "spokesperson"), suggesting an intermediate role in the divine-human communication. The same is true for the word raggimu (masc.)/raggintu (fem.) ("proclaimer"), which is the standard word for prophecy in Neo-Assyrian oracles and letters. Other titles carried by prophets in cuneiform sources include šêlütu (\#\# 74, 114) $)^{1}$ and assinnu (\#\# 7, 22, 23, 124, 126), which are not prophetic titles but refer to other roles of the persons in question; the otherwise unknown word qammatum (\#\# 7, 9, 13), used for one female individual at Mari; and nabûm (\#26), which may be understood as a title of a diviner etymologically related to the Hebrew nāb $\vec{\imath}$.

Each principal designation for a prophetic intermediary highlights one aspect of the prophetic performance. While raggimu refers to the proclamation of the divine message and apilum to its interpretation (especially if understood as "spokesperson" or "interpreter" rather than "answerer"; cf. Merlo 2004; Stökl 2012: 43), muhhûm/mahh $\hat{u}$ indicates the state of mind in which the message was received. Otherwise, it is difficult to recognize clear and systematic differences among the socio-religious profiles of people for whom these designations are used. What unites them is that none of them is known to have been involved in technical divination. At Mari, the muhh ûtm seems to have been 
more closely bound with the temples, while the a pilum had a more independent agency;

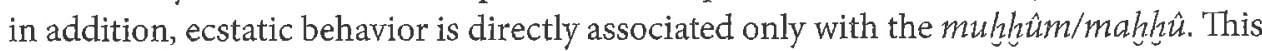
has given reason to the assumption that while apilum and raggimu stand for "professional" prophets, the muhh $\hat{u} \mathrm{~m} / \mathrm{mahh} \hat{u}$ were primarily cultic ecstatics who sometimes prophesied (Stökl 2012). However, whenever the sources reveal anything more specific about the function of muhhum/mahhî, it is virtually always related to prophetic intermediation; hence the mulih $\hat{u} m /$ mahh $h \hat{u}$ fully corresponds to the current definition of a "prophet."

\section{Sources of AnCIENT Near EAstern Prophecy}

\section{The Nature of the Sources}

Everything we know about prophets and prophecy in the ancient Eastern Mediterranean is dependent on written documents. The Hebrew Bible notwithstanding, the corpus of texts documenting prophetic activities and/or the presence of prophets in the ancient Near East consists of approximately 175 texts ranging from the twenty-first to the second century B.C.E. and covering considerable parts of the Near East (Nissinen 2003). Places where prophets and/or prophecy are documented at some point include several cities in Assyria (Arbela, Nineveh, Assur, Calah) and Babylonia (Babylon, Akkad, Uruk, Ur, Dilbat, Larsa, Kǐ̌s, Sippar, Nerebtum), Syrian cities (Mari, Terqa, Der, Aleppo, Tuttul, Andarig, Qațtunan, Hamat, Til Barsib, Chagar Bazar, Harran), and Levantine sites (Byblos, Amman, Deir 'Alla, Lachish). The principal Greek oracle sites were Delphi, Didyma, Dodona, and Claros, flourishing in different periods of time.

Considering the large area and the huge time span, the documents of ancient Near Eastern prophecy are not very numerous, and the distribution-whether chronological or geographical-is anything but even. Roughly seven-eighths of the available written evidence comes from two sites: the eighteenth-century в.C.E. archives of the citystate of Mari, and the seventh-century B.C.E. archives of the Neo-Assyrian Empire at Nineveh. There are conspicuous white spots on the map, such as the city-state of Ugarit, where divination was certainly practiced, but no traces of prophetic activity have been preserved. The texts usually called "Egyptian prophecies" are, in fact, not based on prophetic activity in the previously defined sense; however, some texts accompanying the Egyptian royal cult and recording divine words delivered to the king may refer to the function of priests as intermediaries (Hilber 2013). In the Hittite sources, various kinds of technical divination, such as extispicy and augury, are well known, but it is difficult to identify in them inspired divination other than dreams (see Mouton 2007); at the best, the "man of god" (šiuniyant) mentioned in the Second Plague Prayer of Muršili II, alongside dreams and oracles, may be taken as representing a Hittite prophet (Weippert 2014: 234-235). 
The extant documentation of the ancient Near Eastern prophecy is not only uneven and haphazard-it also consists of very different kinds of sources: written oracles, letters reporting prophetic appearances and dreams, legal and administrative documents, word lists, paraphrases of prophecy in literary contexts, and literary fiction. The types of textual transmission ultimately determine what kind of information is obtainable from each source, and this must be kept in mind when one set of sources is compared with another (Schaper 2013). The available textual sources provide us with everything from firsthand transcript to literary fiction; hence it is absolutely necessary to recognize the function of each text type, since texts were written and preserved for different purposes. Moreover, it is important to distinguish between (quasi-)primary and secondary sources. All written records of oral prophetic messages are, in a way, secondary because of their very writtenness: the words that once came out of the prophets' mouths were necessarily exposed to material restrictions, selection, and memory of the person who wrote them down. However, some texts at our disposal are early transcripts of spoken prophecies, whether in form of an oracle report or as a quotation in a letter, close enough to the oral performance to be considered primary sources. Perhaps the most "neutral" records are the legal and administrative texts that provide us with hard evidence of the presence of prophets in a certain city or temple but rarely tell us much about the prophetic performances. These, again, are described or referred to in royal correspondence, always from the point of view of the writer and for the writer's purposes. Oracle reports in royal archives can be read as reliable accounts of spoken prophetic words; however, even they do not necessarily give a balanced and unbiased picture of prophecy of their time, because certain prophecies were filed away, while others were not. Therefore, even the primary sources do not represent a full portrait of the prophetic phenomenon at a given time and place, but yield only a partial view of it. What we do not see is due to the accident of discovery, and also to deliberate selection. The role of intentional construction becomes even more significant in secondary sources such as quotations of prophetic words in royal inscriptions or descriptions of prophetic performances by biblical and Greek writers.

While the volume of the documentation is tiny as such, its temporal and geographical distribution makes prophecy appear as a constant feature in the Near Eastern socioreligious milieu. The small number of written sources vis-à-vis their large if uneven distribution indicates that prophecies were typically oral performances that never ended up in a written form. Prophecies were sometimes quoted or summarized in written documents, either because the recipient was out of reach, or because the message was found to be of special importance. Written prophecies seem usually not to have been meant for long-time preservation. It is probably not coincidental that the two locations from which the majority of the sources come, Mari and Assyria, also possess the biggest archives found in the Near East.

\section{The Sources from Mari}

The Mari archives have brought to light more than fifty letters and some twenty other texts quoting prophetic oracles or mentioning prophets; some of this material is still 
unpublished (\# 1-65; Durand 1988; Charpin 2012). Most of the letters date from the time of the last king of Mari, Zimri-Lim (ca. 1775-1761 B.C.E.); a few are from the time of his predecessor, Yasmah-Addu (ca. 1792-1775 B.C.E.). The letters form part of ZimriLim's correspondence with his high officials, diviners, and royal women. While the diviners wrote their reports themselves, prophecies and dreams typically were reported to the king in letters written by others who paraphrase the prophecies in the letters, among other issues. The overwhelming majority of the letters is addressed to Zimri-Lim; other recipients include King Yasmah-Addu (\#\# 3, 14), Addu-duri, the mother of Zimri-Lim (\# 45), and some persons belonging to the entourage of the king, Dariš-libur (\# 33) and Su-nuhra-Halu (Charpin 2014: 32-33). All letters with prophetic quotations are addressed to members or officials of the court, which presents the prophetic activity as serving primarily royal interests. The significance of divination in general and prophecy in particular to the king of Mari cannot be doubted, but it must be noted that the royal emphasis is due to the preservation of the documents in the royal archives, which leaves the non-royal functions of prophecy in shadow.

Only one letter has a prophet as its sender: Atamrum, prophet of Šamaš, commissions a scribe to write a letter to the king (\# 48), and this letter, containing four different prophecies, has been preserved on another tablet (\#4). Otherwise, the letters are sent by the king's officials, as well as governors and royal representatives in other cities such as Terqa, Babylon, Tuttul, and Aleppo. A considerable portion of the letters is written by royal women who played an important role as the king's closest advisors: Queen Šibtu (\#\# 17-18, 21-24, 41), the queen mother Addu-duri (\# 5, 35, 42, 43), the king's sister Inib-šina (\#\# 7, 14), and his daughter Šimatum (\# 44). All these people belong to the usual correspondents of the king-only one group of regular letter-writers is missing, conspicuously but understandably: the diviners in their numerous letters never report prophetic performances.

The letters report on prophecies delivered not only at Mari and in other cities of the kingdom (Terqa, Der, Nahur, Saggaratum, Qațtunan), but even outside its borders in Aleppo, Andarig, or Babylon, corresponding to the wide distribution of the prophetic phenomenon in the Near East. The topics dealt with in the majority of the letters fall roughly in two categories: the king's politics and the maintenance of temples. Many prophecies reported in the letters proclaim the victory of Zimri-Lim over the rebelling Yaminite tribes (\#\#10,38) and kings appearing as his rivals and adveraries, such as Hammurapi of Babylon (\#\# 19, 20, 22), Hammurapi of Kurdâ (\# 4), Išme-Dagan of Ekallatum (\#\# 17, 48), and Ibalpiel II of Ešnunna (\#\# 7, 9, 12, 13). The royal women frequently quote prophecies to convince Zimri-Lim of the need to protect himself (\#\# 7,14, 23). In addition to prophecies related to warfare, two letters written by Nur-Sîn report the divine demand for righteousness and justice: "When a wronged man or woman cries out to you, be there and judge their case" (\# 1; cf. \# 2). In this particular case, the justice concerns the ownership of a property located near the city of Aleppo. The maintenance of temples and their worship is another frequently discussed topic in the letters, and cultic instructions are often accompanied by prophetic words. Zimri-Lim is prompted to take care of the cults of the dead, such as the kispum and pagräum offerings (\#\# 30-31, 
38), and to deliver different kinds of cultic equipment to the gods (\#\# 3, 4, 16). Many times he is reminded of his negligence in performing offerings required from him (\#\# 1, $24,25,27,28,29$ ), or in attending to the needs of cultic personnel (\# 8).

In addition to the letters, prophets are mentioned in a number of ritual texts and administrative documents from Mari. Male and female prophets appear together with musicians and other cultic functionaries in the royal ceremony of the ritual of Ištar, which was the most important annual festival at Mari (\#\# 51, 52). Administrative texts mention prophets awarded for their services, often with ordinary garments (\#\# 54-59), but sometimes with more valuable gifts such as silver (\# \#1-63), lances of bronze (\#60), or a donkey (\#53). The single literary reference to prophecy in the sources from Mari is the âpilum who delivers the sign, or appears himself as the sign, of the king's victory in the Epic of Zimri-Lim (\# 64), a unique literary work glorifying the military victories of Zimri-Lim and celebrating the divine support of his kingship (Guichard 2014).

\section{Texts from Assyria}

The second major corpus of evidence of prophecy comes from sixth-century B.C.E. Assyria (\#\# 68-118; Parpola 1997; see also Nissinen 1998). The Neo-Assyrian corpus comprises eleven clay tablets including twenty-nine individual prophetic oracles addressed to Esarhaddon (681-669 B.C.E.) and Assurbanipal (668-627 B.C.E.), kings of Assyria. Of the eleven tablets, three or four (\#\#68-88 plus, probably, what remains of \# 89) contain up to ten individual oracles collected on one tablet, while the rest of the oracles are written each on their own individual tablet. The individual tablets represent the first edition of a written oracle, that is, a report based on a draft written immediately upon the prophetic performance, of which a carefully designed copy was filed away in the archive along with other divinatory reports. The prophecies do not appear as a separate genre, and the scribes could imitate the style of the prophecies in other texts, such as the Dialogue between Assurbanipal and Nabû (SAA 3 13; Atkinson 2013) written by the scribe who also wrote the prophecy in \# 94.

The collections of prophecies consist of individual oracle reports selected and composed to form a thematic collection, representing the second stage of editing. All collections date from the time of Esarhaddon. The oracles, originally dating to 681-679 в.C.E., deal with his rise to power (\#\# 68-77), his enthronement (\#\# 84-88), and the beginning of his reign (\#\# 78-83). The collections were compiled a few years later, in 673 B.C.E., to endorse Assurbanipal's investiture as the crown prince of Assyria. The collections provide rare evidence of a relecture of the prophetic word in a new historical situation, which indicates that the prophecies considered worth preserving were available to the circle of scribes who had access to the royal archives. In the Assyrian case, the reuse of prophecies never developed into prophetic literature comparable to the biblical prophetic books; nevertheless, the scribes who authored, for instance, the Nineveh A inscription of Esarhaddon (RINAP 4 1) used prophecies (šipir maḩhêe) among other divinatory reports as their source material. 
The Assyrian prophecies available to us are the result of a process of transmission and preservation motivated by the kings' purposes to provide evidence of the divine knowledge concerning their rule. They emerge from specific situations in which the kings needed such knowledge; hence they represent a historically contingent and socially determined construct of prophecy corresponding to the state religion and ideology (Parpola 1997: xviii-xliv). Their main, if not only, concern is the king, who appears in quasi-messianic terms as the divinely chosen ruler who has a specific relationship with the goddess Ištar, the most common divine speaker in Assyrian prophecies. Among central topics related to the king are the legitimacy of his succession, the consolidation of his rule, his world dominion and personal safety, and reconciliation between heaven and earth. As in the case of Mari, the solid royal focus of the prophecies available to us blocks the view of non-royal functions of prophecy in the Assyrian Empire.

In addition to the oracles proper, there are well over twenty Neo-Assyrian textsroyal inscriptions, letters, administrative documents, cultic texts, and a treaty-alluding in one way or another to prophets (raggimu/raggintu or mahhiu/mahhütu) or their pronouncements. The royal perspective remains dominant even in these sources; in particular, the prophecies paraphrased in the inscriptions of Esarhaddon and Assurbanipal (\#\# 97-101) represent the very same orthodox ideology as the oracles. Some sources, however, add some information on the use of prophecy and prophetic performances in Assyria. The Vassal Treaty of Esarhaddon acknowledges the possibility that even the prophets may be found among people who speak against the king and the crown prince (102), and such a case is actually documented in the letters of Nabû-rehtu-ușur, who reports on an alleged word of Nusku spoken by a slave girl, according to which the rule of Esarhaddon would come to an end (\#\#115-117).

Scholars and officials writing to the king sometimes justify their opinion with a prophetic quotation in their letters (\#\# 106, 107), but they may also express negative feelings toward prophets because of the king's special favor toward them (\#105) or because of a failed oracle (\# 108). Prophetic performances in a ritual or temple context are reported in a few letters (\#\# 109, 111, 113), and prophets once appear as being present in a sickness ritual (\# 118). A ritual function of the prophets is suggested also by a decree of expenditures for ceremonies in the Ešarra temple in Assur in 809 B.C.E., mentioning female prophets in the section concerning the divine council (\#110).

\section{Other Cuneiform Texts}

Further evidence of the existence of prophets and prophecy in Mesopotamia is scattered among a haphazard selection of individual texts ranging from the twenty-first to the second century B.C.E. and covering considerable parts of the ancient Near East (\#\# 66-67;119-135). The texts represent different genres, such as lexical lists, administrative documents, omen texts, letters, and oracles. Taken together, in spite of its piecemeal character, this documentation gives surprisingly rich information about the socioreligious function of prophets in the ancient Near East. 
Old Babylonian prophetic documents include two oracles to Ibalpiel II, the ruler of the Ešnunna and a contemporary of Zimri-Lim of Mari (\#\# 66-67). The oracles, possibly going back to Ibalpiel's enthronement, are ideologically reminiscent of the Assyrian oracles that date more than a millennium later. Two further Old Babylonian texts have recently been identified as prophecy: a dialogue of the goddess Nanaya and a person identifiable as a prophet regarding a new ruler of Uruk; and an oracle of victory for King Šamšu-iluna spoken by the goddesses Zubaba and Inanna from Kiš (Dalley 2010). Decrees of delivery of food rations and other goods from the Old Babylonian period mentioning prophets have been preserved from the cities of Dilbat (TCL 1 57), Larsa (CM 33 1; TCL 10 34; 39), Ur (TS 1), Sippar (IM 50.852), Nerebtum in Ešnunna (OECT 13 263), Chagar Bazar (Chagar Bazar 176), Tuttul (KTT 53;306), and even from the Elamite capital Susa (MDP 18 171).

Babylonian prophetic oracles have not been preserved from later periods, but some administrative texts testify to the presence of prophets in Neo- and Late Babylonian periods (\#\# 130-133; LKU 51). An astronomical diary from the year 133 B.C.E. reports the ecstatic performance of a messenger of Nanaya in Babylon and Borsippa, inviting an aggressive response from the local authorities (\# 134-135). Administrative texts from Assyria include a Middle-Assyrian food rations list in which male and female prophets appear together with assinnus among the personnel of the temple of Ištar at Kar-Tukulti-Ninurta (\#123), and an outlay of a substantial amount of copper to a prophet at Tušhan in the year 611 B.C.E., that is, after the collapse of Nineveh (ZT'T 25; Parpola 2008).

Lexical lists and omen texts (\#\# 120, 124-129; Erimhuš III; LBTA 2 1; OIP 114 122; SpTU 3 116) do not document the prophets' whereabouts, let alone their oracles; interestingly, however, they regularly associate prophets not only with other non-technical diviners such as dreamers but also with frenzied people (zabbu/zabbatu) and the ambiguously gendered cult functionaries, assinnu and kurgarrû.

\section{Sources from the West}

The prophetic phenomenon in the West Semitic milieu is documented only by a handful of texts, which are, however, enough to testify to the presence of prophets in the Iron Age Levant. Zakkur, king of Hamath, celebrates in his inscription from ca. 800 B.C.E. (\# 137) his victory over seventeen neighboring kings who laid a siege against him in Hazrak, after having received an oracle of Baalšamayin, his patron deity, through seers and visionaries $(h z y n$, 'ddn). The inscription of Deir 'Alla from circa 700 B.C.E. (\# 138 ) reports a vision of the seer $(h z h)$ Balaam son of Beor, also known from the Hebrew Bible (Numbers 22-24), and the content of the vision is a cosmic catastrophe ordained by the council of gods. The roughly contemporaneous Amman Citadel inscription (\# 136) does not mention a prophet, but can be interpreted as an oracle of salvation of Milkom, the patron god of the Ammonites. As to Iron Age Palestine, one of the Lachish ostraca from the late seventh century quotes a one-word oracle- "Beware!"-spoken 
by a prophet (\#139). The word nāb̂̀ appears also one or two other letters from Lachish (\# 141 and, possibly, \# 140)

Prophetic performances in the Levant in earlier times can be found even in two texts written in a non-Semitic language. The Egyptian Report of Wenamon from the eleventh century B.C.E. (\# 142) relates how Wenamon gets into difficulties in Byblos and is relieved only when Amon, his god, possesses a seer (' $d d$ ) who goes into a frenzy and prophesies to the prince of Byblos on his behalf. A tenth-ninth century B.C.E. Luwian stele of Hamiyata, king of Mazuwari (Til Barsib), mentions a prophet giving cultic orders to establish the storm-god Tarhunza after a victorious battle (Tell Ahmar $6 \$ \$$ 21-23; Hawkins 2006).

\section{Written and Literary Prophecy}

Prophetic texts, especially biblical ones, are often read as achievements of individual thinkers, rather than products of societies that used written documents for a variety of purposes. However, the scribal process that produced the texts we have at our disposal is a secondary development with regard to the spoken, "authentic" prophecies. To all appearances, prophets were not supposed to be able to write in any part of the ancient Eastern Mediterranean (Nissinen 2014). The author of the written prophecy, therefore, is the person who adjusted the spoken prophecy to the available space and scribal conventions, deciding what was worth writing down. But this is not the end of the process: the prophetic material was selected by archivists, who chose what they wanted to file away or dispose of. Therefore, the words uttered in the oral performances remain inaccessible. For the same reason, the written sources at our disposal yield only a partial picture of prophetic activities in the ancient Eastern Mediterranean.

The question of how and why prophecy became written down and eventually developed into literature is related to the aims and needs of the communities that perpetuated the process, and hence to the sociology of the scribal culture. Textual evidence of prophetic oracles can be roughly divided into two categories: written prophecy and literary prophecy (Lange 2006). Written prophecy means written records of orally delivered prophetic oracles. These could be prepared for archival purposes, as the Assyrian tablets, but the use of written media could also serve as a surrogate for the oral proclamation if the addressee was out of reach; this is typically the case when prophecies are reported in letters, such as those from Mari, Assyria, or Lachish. Both ways, the purpose is to convey what the author has seen as the essential contents of the oral performance. Literary prophecy, on the other hand, is scribal interpretation of prophecy, either transcending earlier prophecies from the performance situation and recontextualizing in new literary environments, or creating entirely new literary oracles as a part of the editorial history of the given text. Literary prophecy is represented by prophetic quotations in Assyrian and West Semitic inscriptions, but especially by the prophetic books of the Hebrew Bible.

Secondary use of written prophecy is attested already by the collections of prophecies in Assyria, and the Deir 'Alla inscription, the "book" (spr) of Balaam, can be interpreted 
as a secondary compilation of originally independent texts. The Hebrew Bible, however, documents a development that seems not to have happened elsewhere in the Near East, that is, the emergence of prophetic books. In the Persian and Hellenistic periods, prophecy became literary and thus lived on in a textualized form, and the interpretation of earlier texts became a divinatory act. Therefore, it makes sense to use the concept of $b i b$ lical prophecy as referring to prophecy as represented in the literary world of the Hebrew Bible, historically deriving from ancient Hebrew prophecy, of which no primary sources except for two or three letters from Lachish (\#\# 139-141) have been preserved.

\section{Prophecy, Society, AND Religion}

\section{Possessed Intermediaries}

Seeing visions and receiving divine messages can hardly be considered to belong to the everyday experience of the human being. Anthropological evidence shows that the alleged communication with the divine often happens in a physio-psychological state called "ecstasy" or "trance," or, especially with the (emic) assumption of a superhuman agent, "possession" or "inspiration." This terminology pertains to different aspects of an altered state of consciousness, usually accompanied by a performance that makes the performer recognizable as an inspired speaker.

Ample evidence suggests that the altered state of consciousness was an acknowledged element of the public behavior of the prophets (Nissinen 2010). The Akkadian verb mahû implies frantic behavior, and several Near Eastern texts mention ecstatic prophetic performances (\#\# 23, 24, 33, 115, 134, 142). In the newly found fragment of Tablet V of the Epic of Gilgameš, Enkidu says to Gilgameš: "Be furious, like a prophet (äpilum) go into frenzy!" (George and Al-Rawi 2014: 78-79). ${ }^{2}$ The Greek inspired speakers, such as the Pythia at Delphi, were believed to experience divine possession when prophesying (e.g., Plato, Phaedrus, 244a-245a; cf. Flower 2008: 88-91). A number of persons in the Hebrew Bible engage in prophetic ecstasy, make spirit journeys, and see heavenly things (Num 11:25; 1 Sam 10:10; 19:20; 2 Kgs 5:26; 6:17; Ezek 3:12-15; 8; 11; 37:1-14; 40-48; cf. Paul in 2 Cor 12:1-5).

Being possessed by the divine was probably seen as a necessary precondition for intermediation everywhere in the ancient Eastern Mediterranean. More often than not, however, it is not indicated in the sources how the prophetic possession was expected to manifest itself or whether it took place at all. It is probable that people who were believed to be able to transmit divine messages were recognized by their behavior, but the expectations varied as to what kind of comportment was regarded as prophetic. Anthropological evidence proves that possessed performances need not be erratic and uncontrolled, and the altered state of consciousness does not prevent a prophet from delivering an immediately intelligible message (see Stjerna 2001 on Finnish sleeppreachers). Some early Christian writers, however, regarded frenzied behavior as a 
pagan habit, whereas a true biblical or Christian prophet was strictly controlled and non-ecstatic, even under divine inspiration (Origen, Princ. 3, 3, 4-5; Lactantius, Inst. 1, 4, 2-3; see Kaltio 2013: 210-213).

\section{Gender: Divine and Human}

The ancient Eastern Mediterranean sources present prophecy as a strongly gendered category (Stökl and Carvalho [ed.] 2013). The very idea of intermediation implies the "notion of penetration of a human by a divine agent, and casts the prophet into the role of the passive, penetrated, god-possessed female, even when the prophet is, as is usually the case, male" (Kraemer 2013: 291). The agency mediating between the divine and human worlds was likewise gendered: the deities were both malc and female, and the prophets were either male, female, or even of undefinable gender-the gender role of the assinnu who sometimes acts as a prophet is ambivalent enough to be the subject of scholarly debate (cf. Zsolnay 2013).

At Mari, the prophets mostly spoke the words of the state god Dagan and Annunitum, the local manifestation of Ištar; other deities speaking or mentioned as the patron deities of a prophet in Mari prophecies include the male gods Adad, Ikrub-El, Itur-Mer, Nergal, and Šamaš, and the goddesses Belet-ekallim, Diritum, Hišamitum, and Ninhursag. The Ešnunna oracles are spoken by Kititum, a manifestation of Ištar, and in Assyrian prophecies, Ištar is by far the foremost deity of prophecy, most often as Ištar of Arbela or as Mullissu (Ištar of Nineveh). A few prophecies in Assyrian sources are also introduced as words of male deities such as Assur, Bel (Marduk), Nabû, and Nusku. In the extant sources documenting Levantine prophecy, the divine speakers of prophecies are exclusively male gods such as Baalšamayin, Milkom, and Yahweh. In Greece, the principal oracle sites were temples of Apollo, the Greek oracular deity par excellence, or Zeus, as in the case of Dodona.

As to the human party of the prophetic communication, about two-thirds of the prophets in the Mari documents are men, whereas in Assyrian texts, two-thirds are women, probably because of the prominence of Ištar as the oracular deity and the great significance of her temples in the Neo-Assyrian era. In the West Semitic sources, all prophets are of male gender, and in the Hebrew Bible, some fifty male prophets prevail over against half a dozen prophetesses, which may or may not correspond to the actual gender distribution of ancient Hebrew prophets. In Greece, the inspired intermediaries at Delphi, Dodona, and Didyma are women, while male prophets are known from Claros.

The prophetic agency could be claimed and enacted by men and women alike. This can be partly explained by the local prominence of certain deities and their cults, but also by the divine-human gender matrix, in which the humans play the passive role anyway; hence even women could act as mouthpieces of the divine. However, the sources indicate that the agency of the prophets was not purely instrumental, but rather that they also executed an independent agency. Speaking divine words gave especially non-male 
individuals the opportunity to make their own voice heard as well. On the other hand, the suspicion of the male-dominated environment toward prophecies spoken by nonmale persons shows itself at Mari in the more frequent verification of prophecies spoken by a woman or by an assinnu than was the case with words transmitted by male prophets (Hamori 2012).

\section{Prophets and Temples}

The close affiliation between prophets and temples becomes evident from the entire source material, whether Mesopotamian, Greek, or biblical (Nissinen 2012). Temples were centers of the symbolic, mythological universe, where the people participated in the divine presence, which made them an ideal venue for divine-human communication, even by means of prophecy. Some temples feature as particularly important venues of prophetic performances - not only Delphi, Didyma, and Claros, the "big three" Greek sites of Apollonian prophecy, but also the temple of Dagan in Terqa in the kingdom of Mari and the temple of Ištar in the Assyrian city of Arbela.

Prophetic performances took place in temples more typically than other types of divination. A temple can often be imagined as the implied setting of the prophetic oracle even where this is not explicitly mentioned, as in the Zakkur inscription where the word of Baalšamayin follows the prayers of the king of Hamat (\#137). In the correspondence of Mari, the authors of the letters repeatedly report how prophets "arise" (tebû) in temples to deliver a divine message (e.g., \# 5, 29, 42), and prophets are often identified by the name of a deity-for instance, Annu-tabni, prophetess of Annunitum (\# 58)-which probably indicates an affiliation with the temple of the patron deity. The prophets' participation in cultic activities is attested in the case of the ritual of Ištar, which includes an interplay between prophets and musicians (\# 51-52). Neo-Assyrian letters, too, sometimes mention prophecies uttered in temples (e.g., \# 111), and the colophons of written oracles localize a prophet by the name of a city. When the colophon says, "Tašmetu-ereš, the p[rophet], prop[hesied this i]n Arbela" (\# 91), this can be taken as a reference to a prophecy uttered in the temple of Ištar in Arbela, which was the principal source of Assyrian prophecy. In the Hebrew Bible, the books of Samuel and Kings include narratives in which a place of worship is explicitly or implicitly presented as the venue of the prophetic performances (1 Sam 2:27-36; 1 Kgs 11:29-39; 14:1-18). The prophetic books tend to juxtapose priests and prophets (Jer $2: 8 ; 4: 9-10 ; 5: 31 ; 6: 13-15 ; 8: 1,10-12 ; 23: 11,33$; 26:7-8, 16; 29:1; Hos 4:4; Zeph 3:4; cf. 2 Kgs 23:2), and prophets, such as Jeremiah, are brought to the temple over and over again (Jer 7:1-15; 26:1-19; 28;38:14).

Belonging to the temple personnel was not as such the prerequisite of the prophetic role. As gods were believed to be free to communicate with anyone, prophetic dreams and oracles could be received and communicated by any ordinary person whose agency and social status were otherwise limited in that community, such as a slave. It is usually difficult to know whether a prophet who performed in a temple actually was employed by it (Fleming 2004). Nevertheless, prophets were permanently present in the major 
Greek oracle sites, Mesopotamian administrative documents from different times mention prophets among the temple personnel (\#\# 110, 119, 123, 130; CM 33 1; LKU 51), and the strong presence of prophets in the temple of Ištar in Arbela indicates their permanent function in the worship of the goddess; some of them actually lived in the temple as votaresses (\#\# 74, 114). The temples provided the most likely setting for the activity of "professional" prophets, that is, persons whose permanent role and source of income was prophetic intermediation.

Whether or not permanently affiliated with the temples in (or about) which the prophets prophesied, they are often to be found as advocates of temples and their worship. The letters from Mari repeatedly report prophecies ordering the king to perform sacrifices, sometimes rebuking him for his negligence in this respect. The Assyrian correspondence includes prophecies concerning the temple property, indicating even some clashes between prophets and temple administrators (\#\# 111, 113). Assurbanipal mentions dreams and prophetic oracles prompting him to renovate the temple of the Lady of Kidmuri in Calah (\# 99), and the same happened later in the Greek world: the Didymean priests consulted the oracle in order to speed up the completion of the construction works of their temple (DI 47). In Greek temples, dedications to gods were based on instructions pronounced by an oracle, for instance, "Hermias to Zeus Hypsistos, a thank-offering in accordance with an oracle" (DI 129). Oracular responses from Delphi and Didyma recorded in primary sources such as inscriptions are, for the most part, related to cult and religion (Fontenrose 1988: 96), and many of the preserved oracles from Claros (Merkelbach and Stauber 1996) give cultic instructions.

Even in biblical prophecy, the significance of the temple of Jerusalem as the site and symbol of the divine presence is beyond any doubt. Especially in the books of Haggai, Zechariah, and Ezekiel, the temple of Jerusalem exceeds every other topic in importance. The so-called cultic criticism of the biblical prophets (e.g., Isa 1:11-17; 58; Amos 5:21-24; Hos 6:4-6; Mic 6:6-8; Zech 7:5-10), often interpreted as an expression of ideological antiritualism, should be interpreted as a concern for, rather than as an antagonism to, the temple worship. That these texts present the religious order as failing to maintain the symbolic universe does not diminish the significance of the temple as its center.

\section{Prophets and Kings}

Prophecies are virtually always addressed to kings in the ancient Near Eastern texts: Zimri-Lim of Mari, Ibalpiel of Ešnunna, Esarhaddon and Assurbanipal of Assyria, Zakkur of Hamath, or the Prince of Byblos. In Greek sources, too, kings are frequently found consulting oracles-not only rulers of Greek city-states but also kings of more remote lands. The Delphic oracle, for instance, was consulted by Gyges, Alyattes, and Croesus (kings of Lydia), Arkesilaos II and III of Cyrene, Ptolemy of Egypt, Philip II of Macedonia, and the Roman emperors Augustus, Nero, and Julian (see the catalog in Fontenrose 1978: 240-416). Even in the Hebrew Bible, kings from Saul to Zedekiah turn to prophets, and prophecy accompanies the rise and fall of kingship in Judah and Israel. 
Throughout the source material, there is a conspicuous affiliation between the institutions of prophecy and kingship. Prophecy had a political function as the source of divine knowledge necessary for the appropriate maintenance of the society, whether a Near Eastern monarchy or a Greek city-state. All over the ancient Eastern Mediterranean, rulers consulted prophets, among other diviners, to find legitimation for their rule and actions. Prophets may not generally have enjoyed quite as high an appreciation as technical diviners who, at least in Mesopotamia, belonged to the king's immediate entourage; nevertheless, prophecy was another medium through which the king was informed of the divine favors as well as his own duties (Charpin 2012; Pongratz-Leisten 1999). On the other hand, prophets, like other diviners, depended on the royal recognition of their divinatory skills.

The cummunication between prophets and kings, hherefore, was bidirectional: kings turned to prophets to receive divine advice, and prophets made the king conversant with the divine will, and sometimes also with their own needs (e.g., \# 8). The patterns of communication between prophets and kings appear to be similar throughout the sources. Prophecies may be solicited, as is usual in Greek sources, or unsolicited, as is more often than not the case in the Near East; the Hebrew Bible knows both options. The majority of extant Near Eastern prophecies are supportive and favorable to the kings, but the position of the prophets as mouthpieces of the divine enabled even a critical stance toward their actions. Judgmental prophecies are less common in the texts available to us; this does not necessarily indicate that they were not proclaimed as often as oracles of encouragement and salvation, although it seems to have been less than usual to preserve such messages for posterity.

The strong royal emphasis of the extant Near Eastern texts may go back to their origin in royal archives. It is conceivable that private persons, too, turned to prophets in the ancient Near East, but the extant sources do not let us know much about such communication. In Greek sources, the typical inquirer of an oracle is not a king but a citizen of a city-state, and the Greek sources, unlike the Near Eastern ones, allow us to see the role of private people as addressees of prophetic intermediation. The somewhat different role of kings as consultants of Greek oracles may also be due to different political structures. The principal Greek oracle sites were more independent of the rulers than the Near Eastern prophets, and they also had a more international character. The Delphic Pythia delivered oracles to kings coming from different corners of the Mediterranean, while the Assyrian prophets would rather communicate only with the Assyrian king. Moreover, insofar as the secondary source material reveals historical realities, the Greek oracles were less dependent on the state ideology that characterizes the prophecies preserved from Mesopotamia. The Hebrew Bible, again, constitutes a specific case with its unique editorial history. The encounters between prophets and kings are embedded in a secondary literary setting, which makes it difficult to reconstruct historical circumstances. While the function of the prophets is by and large the same as in other ancient Near Eastern sources, the relationship between kings and prophets appears as more immediate and the role of the prophets as more independent than in any Near Eastern source. On the other hand, the harsh antagonism 
toward kings and kingship in the Hebrew Bible is unparalleled and may reflect postmonarchic ideologies.

\section{Prophecy: A Common Eastern Mediterranean Phenomenon}

The ancient Near Eastern, Greek, and biblical texts make available a manifold, if fragmentary, documentation of prophetic intermediation. Enough commonalities can be found in this large source material to warrant the assumption of the existence of a common ancient Fastern Mediterranean prophetic phenomenon. The common features include the social function of inspired intermediation as one type of divination; the socio-religious context of the prophets in temples; the political significance of prophecy for the institution of kingship; the altered state of consciousness as the precondition of prophesying; and the gender matrix allowing the prophetic agency of both male and non-male persons.

The comparison between the source materials also reveals differences, of course, both in the historical image of the prophetic phenomenon and in the function and purpose of the sources themselves. The differences may demonstrate both continuity and discontinuity and, therefore, do not disprove the historical connection. There is no reason to believe that Greek, Mesopotamian, and biblical prophecy represent three distinct and disconnected socio-religious phenomena; neither is there a need to look for an "authentic" source of prophecy asking "who was first?" or "first from where?" Instead, the study can focus on family resemblances; in any case, the Eastern Mediterranean sphere is geographically restricted enough to increase the probability of historical connection and cultural interaction.

\section{Notes}

1. Henceforth, the numbers of texts (\#) refer to Nissinen 2003.

2. I thank Daniel E. Fleming for drawing my attention to this text.

\section{For FurTHER REAdiNG}

Atkinson, Jason. 2013. "Prophecy in K1285? Re-evaluating the Divine Speech Episodes of Nabû.." Pages 59-89 in "Thus Speaks Ishtar of Arbela": Prophecy in Israel, Assyria, and Egypt in the Neo-Assyrian Period. Edited by Robert P. Gordon and Hans M. Barstad. Winona Lake, IN: Eisenbrauns.

Charpin, Dominique. 2012. "Le prophétisme dans le Proche-Orient d'après les archives de Mari." Pages 31-73 in Les recueils prophétiques de la Bible: Origines, milieux, et contexte proche-oriental. Edited by Jean-Daniel Macchi, Christophe Nihan, Thomas Römer, and Jan Rückl. Le Monde de la Bible 64. Geneva: Labor et Fides. 
Charpin, Dominique. 2014. "Prophéties et rêves 'censurés' dans les archives royales de Mari." Pages 23-33 in Comment devient-on prophète? Actes du colloque organisé par le Collège de France, Paris, les 4-5 avril 2011. Edited by Jean-Marie Durand, Thomas Römer, and Micaël Bürki. OBO 265. Fribourg: Academic Press; and Göttingen: Vandenhoeck \& Ruprecht.

Dalley, Stephanie. 2010. "Old Babylonian Prophecies at Uruk and Kish." Pages 85-97 in Opening the Tablet Box: Near Eastern Studies in Honor of Benjamin R. Foster. Edited by Sarah C. Melville and Alice L. Slotsky. CHANE 42. Leiden: Brill.

de Jong, Matthijs J. 2007. Isaiah among the Ancient Near Eastern Prophets: A Comparative Study of the Earliest Stages of the Isaiah Tradition and the Neo-Assyrian Prophecies. VTSup 117. Leiden: Brill.

Durand, J.-M. 1988. Archives épistolaires de Mari I/1. ARM 26/1. Paris.

Fleming, Daniel E. 2004. "Prophets and Temple Personnel in the Mari Archives." Pages 44-64 in The Priests in the Prophets: The Portrayal of Priests, Prophets and Other Religious Specialists in the Latter Prophets. Edited by Lester L. Grabbe and Alice Ogden Bellis. JSOTSup 408. London and New York: T \& T Clark.

Flower, Michael A. 2008. The Seer in Ancient Greece. Berkeley: University of California Press.

Fontenrose, Joseph. 1978. The Delphic Oracle: Its Responses and Operations with a Catalogue of Responses. Berkeley: University of California Press.

Fontenrose, Joseph. 1988. Didyma: Apollo's Oracle, Cult, and Companions. Berkeley: University of California Press.

George, Andrew, and Al-Rawi, Faruk N. H. 2014. "Back to the Cedar Forest: The Beginning and End of Tablet V of the Standard Babylonian Epic of Gilgames." JCS 66: 69-9o.

Guichard, Michaël. 2014. Florilegium Marianum 14: L'Épopée de Zimri-Lîm. Mémoires de NABU 16. Paris: SEPOA.

Hamori, Esther J. 2012. "Gender and the Verification of Prophecy at Mari." WO 42: 1-22.

Hawkins, J. David. 2006. "Inscription." Pages 11-31 in Guy Bunnens, A New Luwian Stele and the Cult of the Storm-God at Til Barsib-Masuwari. Tell Ahmar 2. Leuven: Peeters.

Hilber, John. 2013. "Royal Cultic Prophecy in Assyria, Judah, and Egypt." Pages 161-186 in "Thus Speaks Ishtar of Arbela": Prophecy in Israel, Assyria, and Egypt in the Neo-Assyrian Period. Edited by Robert P. Gordon and Hans M. Barstad. Winona Lake, IN: Eisenbrauns.

Kajava, Mika, ed. 2013. Studies in Ancient Oracles and Divination. Acta Instituti Romani Finlandiae 40. Rome: Institutum Romanum Finlandiae.

Kaltio, Outi. 2013. "Valuing Oracles and Prophecies: Lactantius and the Pagan Seers." Pages 199-213 in Studies in Ancient Oracles and Divination. Edited by Mika Kajava. Acta Instituti Romani Finlandiae 40. Rome: Institutum Romanum Finlandiae.

Kraemer, Ross Shepard. 2013. "Gender." Pages 281-308 in The Cambridge Companion to Ancient Mediterranean Religions. Edited by Barbette Stanley Spaeth. New York: Cambridge University Press.

Lampinen, Antti. 2013. "Theō memelēmene Foibō: Oracular Functionaries at Claros and Didyma in the Imperial Period." Pages 49-88 in Studies in Ancient Oracles and Divination. Edited by Mika Kajava. Acta Instituti Romani Finlandiae 40. Rome: Institutum Romanum Finlandiae.

Lange, Armin. 2006. "Literary Prophecy and Oracle Collection: A Comparison between Judah and Greece in Persian Times." Pages 248-275 in Prophets, Prophecy, and Prophetic Texts in Second Temple Judaism. Edited by Michael H. Floyd and Robert D. Haak. LHBOTS 427. New York and London: T \& T Clark. 
Merkelbach, Reinhold, and Josef Stauber. 1996. "Die Orakel des Apollon von Klaros," Epigraphica Anatolica 27: 1-53.

Merlo, Paolo. 2004. “äpilum of Mari: A Reappraisal." UF 36: 323-332.

Mouton, Alice. 2007. Rêves hittites: Contribution à une histoire et une anthropologie du rêve en Anatolie ancienne. CHANE 28. Leiden: Brill.

Nissinen, Martti. 1998. References to Prophecy in Neo-Assyrian sources. SAAS 7. Helsinki: The Neo-Assyrian Text Corpus Project.

Nissinen, Martti, with contributions by C. L. Seow and Robert K. Ritner. 2003. Prophets and Prophecy in the Ancient Near East. SBLWAW 12. Atlanta: Society of Biblical Literature.

Nissinen, Martti. 2010. "Prophetic Madness: Prophecy and Ecstasy in the Ancient Near East and in Greece." Pages 3-29 in Raising Up a Faithful Exegete: Essays in Honor of Richard D. Nelson. Edited by K. L. Noll and Brooks Schramm. Winona Lake, IN: Eisenbrauns.

Nissinen, Martti. 2012. "Prophètes et temples dans le Proche-Urient ancient et les textes bibliques." Pages 74-111 in Les recueils prophétiques de la Bible; Origines, milieux, et contexte proche-oriental. Edited by Jean-Daniel Macchi, Christophe Nihan, Thomas Römer, and Jan Rückl. MdB 64. Geneva: Labor et Fides.

Nissinen, Martti. 2013. "Prophecy as Construct: Ancient and Modern." Pages 11-35 in "Thus Speaks Ishtar of Arbela": Prophecy in Israel, Assyria, and Egypt in the Neo-Assyrian Period. Edited by Robert P. Gordon and Hans M. Barstad. Winona Lake, IN: Eisenbrauns.

Nissinen, Martti. 2014. "Since When Do Prophets Write?" Pages 585-606 in In the Footsteps of Sherlock Holmes: Studies in the Biblical Text in Honour of Anneli Aejmelaeus. Edited by Kristin de Troyer, T. Michael Law, and Marketta Liljeström. CBET 72. Leuven: Peeters.

Parpola, Simo. 1997. Assyrian Prophecies. SAA 9. Helsinki: Helsinki University Press.

Parpola, Simo. 2008. "Cuneiform Texts from Ziyaret Tepe (Tušhan), 2002-2003." SAAB 17: 1-113.

Pongratz-Leisten, Beate. 1999. Herrschaftswissen in Mesopotamien: Formen der Kommunikation zwischen Gott und König im 2. und 1. Jahrtausend v. Chr. SAAS 10. Helsinki: The NeoAssyrian Text Corpus Project.

Pyysiäinen, Ilkka. 2009. Supernatural Agents: Why We Believe in Souls, Gods, and Buddhas. New York: Oxford University Press.

Schaper, Joachim. 2013. "Prophecy in Israel and Assyria: Are We Comparing Apples and Pears? The Materiality of Writing and the Avoidance of Parallelomania." Pages 225-238 in "Thus Speaks Ishtar of Arbela": Prophecy in Israel, Assyria, and Egypt in the Neo-Assyrian Period. Edited by Robert P. Gordon and Hans M. Barstad. Winona Lake, IN: Eisenbrauns.

Stjerna, Kirsi. 2001. "Finnish Sleep-Preachers: An Example of Women's Spiritual Power." Nova Religio 5: 102-120.

Stökl, Jonathan. 2012. Prophecy in the Ancient Near East: A Philological and Sociological Comparison. CHANE 56. Leiden: Brill.

Stökl, Jonathan, and Corrine L. Carvalho, eds. 2013. Prophets Male and Female: Gender and Prophecy in the Hebrew Bible, the Eastern Mediterranean, and the Ancient Near East. AIL 15. Atlanta: Society of Biblical Literature.

Weippert, Manfred. 2014. Götterwort in Menschenmund: Studien zur Prophetie in Assyrien, Israel und Juda. FRLANT 252. Göttingen: Vandenhoeck \& Ruprecht.

Zsolnay, Ilona. 2013. "The Misconstrued Role of the Assinnu in Ancient Near Eastern Prophecy." Pages 81-99 in Prophets Male and Female: Gender and Prophecy in the Hebrew Bible, the Eastern Mediterranean, and the Ancient Near East. Edited by Jonathan Stökl and Corrine L. Carvalho. AIL 15. Atlanta: Society of Biblical Literature. 